\title{
Effect of lead design and pacing vector on electrical parameters of quadripolar coronary sinus leads: The RALLY-X4 study
}

\section{Burri, Haran}

2019-07

Burri , H , Schrage , M O , Morani , G , Sakata , Y, Hermida , J-S , Solimene , F , Rauwolf , T , Kayser , T , Pakarinen , S \& Biffi , M 2019 , ' Effect of lead design and pacing vector on electrical parameters of quadripolar coronary sinus leads: The RALLY-X4 study ' , Pacing and Clinical Electrophysiology , vol. 42 , no. 7 , pp. 1018-1025 . https://doi.org/10.1111/pace.13716

http://hdl.handle.net/10138/314617

https://doi.org/10.1111/pace.13716

unspecified

acceptedVersion

Downloaded from Helda, University of Helsinki institutional repository.

This is an electronic reprint of the original article.

This reprint may differ from the original in pagination and typographic detail.

Please cite the original version. 


\section{HeartLogic \\ Heart Failure Diagnostic}

\section{SOME TECHNOLOGY IS GAME CHANGING.}

\section{THIS IS CAREER DEFINING.}

Lead the way with HeartLogic" from Boston Scientific. The first and only FDA-approved heart failure alert validated to have: high sensitivity, the ability to provide weeks of advanced notice, and low alert burden for detecting worsening heart failure. This is your time. It's your move.

Only available in the Boston Scientific Resonate $^{\text {Tu }}$ family of CRT-Ds and ICDs. 
Effect of lead design and pacing vector on electrical parameters of quadripolar coronary sinus leads: the RALLY-X4 study

Short title: Lead design and electrical parameters

Haran Burri, MD ${ }^{1}$ Max Olaf Schrage, $M^{2}$ Giovanni Morani, $\mathrm{MD}^{3}$ Yasushi Sakata, MD ${ }^{4}$ Jean-Sylvain Hermida, $M D^{5}$ Francesco Solimene, $\mathrm{MD}^{6}$ Thomas Rauwolf, Dr Ing. ${ }^{7}$ Torsten Kayser, PhD, ${ }^{8}$ Sami Pakarinen, $\mathrm{MD}^{9}$ Mauro Biffi, $\mathrm{MD}^{10}$

\section{From:}

${ }^{1}$ University Hospital of Geneva, Switzerland

${ }^{2}$ Unfallkrankenhaus, Berlin Marzahn, Germany

${ }^{3}$ Ospedale Borgo Trento, Verona, Italy

${ }^{4}$ Osaka University, Osaka, Japan

${ }^{5}$ CHU Amiens- Hôpital Sud, Amiens, France

${ }^{6}$ Clinical Montevergine, Mercogliano, Italy

${ }^{7}$ University Magdeburg, Margeburg, Germany

${ }^{8}$ Boston Scientific Inc

${ }^{9}$ Helsinki University Hospital, Helsinki, Finland

${ }^{10}$ Policlinico S Orsola-Malpighi University Hospital, Bologna, Italy

\section{Address for correspondence:}

Prof Haran Burri

Cardiac pacing Unit, Cardiology Department

University Hospital of Geneva

Rue Gabrielle Perret Gentil 4

1205 Geneva, Switzerland

This article has been accepted for publication and undergone full peer review but has not been through the copyediting, typesetting, pagination and proofreading process, which may lead to differences between this version and the Version of Record. Please cite this article as doi: 10.1111/pace.13716.

This article is protected by copyright. All rights reserved. 
e-mail: haran.burri@hcuge.ch

phone: +4122 3727200

Word count: 3'026 words including abstract of 226 words, text and references.

Disclosures: H.B. has received speaker fees and research grants from Abbott, Biotronik, Boston Scientific, Medtronic and Microport.

T.K. is an employee of Boston Scientific and is scientist working on RALLY-X4.

Funding: The RALLY-X4 study was funded by Boston Scientific.

\section{ABSTRACT}

Background: Various lead designs have been developed to accommodate different coronary sinus anatomies. Our objectives were to compare electrical parameters of straight and spiral left ventricular leads, to evaluate capture thresholds and impedances using different pacing vectors, and to study evolution of thresholds over time.

Methods: The RALLY-X4 study enrolled patients implanted with a lead from the Acuity X4 family (Straight, Spiral Short or Spiral Long). Electrical parameters (including capture thresholds from all 17 vectors) were measured at baseline and follow-up.

Results: Data from 795 patients who were successfully implanted were analysed. Straight and spiral leads had similar proportions of patients with thresholds $<2.5 \mathrm{~V} / 0.4 \mathrm{~ms}$ using the distal electrode (61$65 \%$ of patients) or from at least one of the proximal (E2-E4) electrodes (81-83\% of patients). Unipolar vectors had significantly lower thresholds and impedances than bipolar vectors, with similar measurements compared to extended bipolar configurations. Capture thresholds increased with more proximal electrodes for all leads. Over a mean follow-up of one year, a slight decrease in capture thresholds was observed. 
Conclusion: Straight and spiral quadripolar leads allow to obtain clinically acceptable capture thresholds from at least one of the proximal electrodes in $>80 \%$ of patients. Pacing vectors significantly affect electrical parameters, with higher thresholds in more proximal electrodes and lower thresholds with unipolar and extended bipolar configurations. Capture thresholds slightly decreased over a mean follow-up of one year.

Keywords: Cardiac resynchronization therapy; pacing leads; capture threshold; impedance.

\section{INTRODUCTION}

The most important aspects of left ventricular (LV) lead position for cardiac resynchronization therapy (CRT) are hemodynamic effect, stability, and adequate electrical parameters. Quadripolar LV leads have had a significant impact in this therapy by providing more programming options to maximize CRT delivery. A meta-analysis of eight studies (1) and a report with a large real-world experience (2) have shown that quadripolar leads have lower rates of implantation failure, post-operative lead dislodgement, revision or deactivation. Clinical outcome in terms of mortality and heart failure hospitalization have also been shown to be reduced with quadripolar leads compared to bipolar leads in a non-randomized but matched population.(3) Manufacturers propose quadripolar leads of different diameters, shapes and interlead spacing to address variations in coronary sinus (CS) tributary anatomy. Boston Scientific (Marlborough, MA) offer the ACUITY X4 lead family which are either of a straight or a spiral shape, with 17 different programmable vectors - (see figure 1). The performance of this lead family has been previously described.(4; 5) In the NAVIGATE X4 study,(5) there was an overall LV-lead 6-month complicationfree rate of $98 \%$ in 791 patients. However, not all pacing vectors were tested in this study, and follow-up was limited to 6 months without reporting evolution of thresholds. 
The RALLY-X4 study is a post-market surveillance registry for Acuity X4 leads, where investigators were encouraged to report electrical parameters for all 17 vectors at each follow-up. This provided us with the opportunity to study in detail different pacing vectors in a large dataset. Our aims were to compare1) electrical measurements of straight and spiral leads 2) capture thresholds and pacing impedances of different pacing polarities and 3) to study evolution of capture thresholds over time for straight and spiral leads.

\section{METHODS}

\section{Study design}

The RALLY-X4 study was a non-randomized, unblinded, multicentre observational study conducted in 82 centres in Europe, Japan, Singapore, Hong Kong and Colombia. All patients were implanted with a biventricular defibrillator (CRT-D) and an Acuity X4 lead (the lead model was left to the discretion of the investigator). Implant procedure and subsequent follow ups were based on hospital standards. The study collected patient indication and demographics, all adverse events, and selected programming data.

LV Capture thresholds were measured at $0.4 \mathrm{~ms}$, and investigators were encouraged to report electrical measurements for each of the 17 programmable vectors at baseline and at close out visits. In order to account for electrodes with non-capture, which are not taken into account when calculating median thresholds, we evaluated the proportion of electrodes for each lead with capture thresholds (in any configuration) at baseline based upon an arbitrary cutoff of $2.5 / 0.4 \mathrm{~ms}$ (as previously reported $(5 ; 6))$. Blank fields were assumed to be non-capture and counted as thresholds 
$>2.5 \mathrm{~V}$. Evolution of thresholds was evaluated by paired measurements of the unipolar vector for each electrode at baseline and the closeout visits.

Occurrence of phrenic nerve stimulation (PNS) and any loss of function of the LV lead or requirement for lead repositioning were reported and counted toward the study endpoint. Final lead position (based on the lead tip), baseline and close out ECGs were assessed by corelabs based upon uploaded files, fluoroscopic or X-ray images. The study was approved by the institutional ethics committees, and all patients provided written informed consent.

\section{Statistical analysis}

Analysis was performed using the SAS 9.4 software (Cary, USA). Descriptive statistics report values as mean $\pm S D$ or median \pm interquartile range, as appropriate. Differences between groups were evaluated using the Chi-squared and Kruskal-Wallis test. Changes in electrical parameters over time were evaluated for each cathode by paired analyses at baseline and at last follow-up using the Wilcoxon signed rank test. A P value of $<0.05$ was considered statistically significant.

\section{RESULTS}

\section{Patient population}

Of the 863 patients enrolled, 838 underwent a procedure and 795 patients $(94.9 \%)$ were successfully implanted with an Acuty X4 lead (one patient at the second attempt). Patient demographics are shown in table 1. A total of 147 patients discontinued the study, of whom 54 died. Mean follow-up was $12.8 \pm 5.9$ months. 


\section{General findings}

Spiral leads were more often placed in an apical position than straight leads, without any differences in anterior versus non-anterior lead position (table 2). Of the 155 patients evaluated by the corelab as having the lead tip in an apical position, 143 had sufficient electrical data for analysis. Of these, 113 (79\%) had E3 and/or E4 with a capture threshold of $<2.5 \mathrm{~V} / 0.4 \mathrm{~ms}$.

A PNS-related adverse event was reported in 49 (5.8\%) patients at six months follow-up, of whom lead revision was required in four (0.5\%) patients with no additional cases between the six and 12-month timepoints. Details on PNS with different pacing configurations were available in 726 patients. PNS in at lead one configuration for Straight, Spiral Short and Spiral Long leads were reported in $10.9 \%, 3.7 \%$ and $5.9 \%$ of cases respectively. PNS was associated with E1 (4.7\%), E2 (4.6\%), E3 (2.6\%) and E4 (10.7\%). Polarities associated with PNS were unipolar (10.3\%), extended bipolar (4.8\%) and bipolar (2.7\%). Pectoral muscle stimulation was not reported in any patient programmed to a unipolar pacing configuration.

There were a total of $6(0.8 \%)$ lead dislodgements over the course of the study, of whom four patients underwent revision, one lead explantation and one lead inactivation.

At the programmed vectors for LV pacing and sensing at baseline and closeout visits for each lead model, the median values for capture thresholds were 1.0-1.3V, for pacing impedance, 683-736 Ohms and for sensing amplitudes, 13.9-17.0mV.

\section{Comparison of electrical parameters between leads}

The results of electrical parameters in 795 patients at baseline are shown in table 3. Data fields for thresholds measurements of the 17 possible vectors in each patient were left blank in $21.7 \%$ of fields and were assumed to be non-capture.

This article is protected by copyright. All rights reserved. 
In order to analyse separately distal E1 electrodes which are often implanted in an apical position and the proximal E2-4 electrodes (which are most often used to avoid apical pacing associated with reduced response to $\mathrm{CRT}(7 ; 8))$, we performed an analysis comparing the numbers of proximal electrodes which offered thresholds $<2.5 \mathrm{~V}$ (see figure 2 ). The proportions of patients with Straight, Spiral Short and Spiral Long leads with E1 thresholds $<2.5 \mathrm{~V}$ were $65 \%, 64 \%$ and $61 \%$ respectively; the same analysis for at least one proximal electrode (E2-4) were $81 \%, 83 \%$ and $83 \%$ respectively $(\mathrm{P}=\mathrm{NS})$. The Straight lead had a significantly greater proportion of patients with two or all three proximal electrodes with low thresholds: $59 \%$ versus $48 \%$ for Spiral Short $(P=0.013)$ and 39\% for Spiral Long $(P<0.0001)$. There were no differences between spiral leads.

\section{Effect of pacing vector on capture thresholds and lead impedance}

As shown in table 3 , pacing vectors had a highly significant impact on capture threshold and lead impedance for all four electrodes of all three leads. Unipolar and extended bipolar configurations (see figure 1) had in general lower capture thresholds than true bipolar configurations, except for the E4 electrode of spiral leads. In general, extended bipolar configurations had similar thresholds compared to unipolar vectors. Different bipolar pacing vectors for a given cathode (e.g. E1-E2, E1-E3 and E1-E4) had no significant impact on thresholds for any electrode of any lead.

The E1 and E2 electrodes usually had greatest (and similar) proportions of low thresholds, whereas the proportion of low thresholds decreased with E3 and E4 electrodes. Regarding impedances, unipolar vectors were approximately $50-60 \%$ of those for bipolar vectors $(P<0.001$ for all comparisons) and approximately $90 \%$ of extended bipolar vectors ( $\mathrm{P}<0.05$ for all comparisons). 


\section{Evolution of capture thresholds and pacing impedances over time}

The data are displayed in figure 3. Overall, we observed a slight reduction in capture thresholds, a slight decrease in E1 pacing impedance and a slight increase in pacing impedance of the E2-4 electrodes. An approximation of the current drain was calculated by I=V/R, although the actual value would result from the programmed output voltage, and not the threshold voltage.

\section{DISCUSSION}

The main findings of our study are that 1) Straight and Spiral leads perform well with high implant success and low dislodgment rates at one-year follow up 2) Capture thresholds of $<2.5 \mathrm{~V} / 0.4 \mathrm{~ms}$ are obtained from at least one proximal electrode (E2-4) in $>80 \%$ of cases 3 ) Unipolar and extended bipolar vectors yield significantly lower thresholds and impedances compared to bipolar configurations 4) Capture thresholds most often show a slight decrease over follow-up with all lead types.

A proximal (E2-4) electrode was used as a cathode in the majority of patients in our study (63-74\% depending on the lead model), most probably in order to avoid pacing from an apical site (where lead tips are often wedged for stability), as is currently recommended.(9) The NAVIGATE X4 study showed that proximal electrode thresholds were lower with spiral leads compared to straight leads.(5) Overall, $91 \%$ patients implanted with a spiral lead had a threshold $<2.5 \mathrm{~V}$ from a "bestproximal" electrode (median $0.9 \mathrm{~V}[\mathrm{IQR} 0.7,1.3]$ ). The same analysis for the straight leads yielded a proportion of $83 \%(\mathrm{P}=0.003)$ with higher absolute thresholds (median $1.3 \mathrm{~V}[\mathrm{IQR} 0.9,2.2])$. This is in contrast with our findings which show that all three lead types had a similar proportion of patients $(81-83 \%)$ with at least one proximal electrode with a threshold $<2.5 \mathrm{~V}$, and in fact a higher proportion 
of patients with at least two or all three proximal electrodes with low thresholds in patients with straight leads. Differences in findings with the NAVIGATE X4 study may be possibly explained by the fact that all 17 pacing vectors were evaluated for our analysis, whereas this was not the case for NAVIGATE X4. In fact, a significantly higher proportion of patients with straight leads than spiral leads had at least two or all three proximal electrodes with thresholds $<2.5 \mathrm{~V}$. The spiral design of the leads probably resulted in fewer proximal electrodes having good myocardial contact, which explains this finding. An additional finding was that E3 and E4 electrodes had higher thresholds, and this was consistent for all lead models. Interestingly, the same findings were reported in leads with different designs from other manufacturers, $(6 ; 10 ; 11)$ and possibly stem from less intimate contact with the myocardium of these electrodes. Capture thresholds are also likely to be affected by the anatomy of the coronary sinus tributary (vessel diameter, tortuosity etc). Not surprisingly, we found that lead models were positioned differently e.g. Spiral leads were more often in an apical position (and probably in larger veins) than Straight leads. This is an important confounding factor which needs to be accounted for when comparing performance of different lead models.

In agreement with our findings, previous studies using leads from other manufacturers have reported that extended bipolar pacing vectors yield lower capture thresholds than bipolar configurations. $(6 ; 10)$ For the first time, we also report unipolar vectors (currently only available on CRT-Ds of Boston Scientific) and found them to be comparable to extended bipolar vectors. The advantage of unipolar pacing is avoidance of anodal capture (which, although less likely with the RV coil of and ICD lead than with the ring of a pacing lead, is still possible(12)). This may be an issue if sequential biventricular pacing with left ventricular pre-excitation is desired, or in case of device follow-up with non-identification of LV lead dislodgment. However, the tradeoff with unipolar and extended bipolar vectors compared to bipolar configurations is a lower pacing impedance (which was also reported in the NAVIGATE-X4 study(5)), as this leads to higher current drain. Another possible drawback in case of high pacing output in the unipolar configuration is pectoral muscle 
capture. The most frequently programmed vectors in our study were extended bipolar for all three leads.

Comparison of electrical performance between Acuity X4 leads and quadripolar leads of other manufacturers is difficult, owing to differences in reporting of data e.g. capture thresholds measured at $0.5 \mathrm{~ms}$ pulsewidth and expressed as mean $\pm \mathrm{SD}$ in these reports $(6 ; 10)$ compared to $0.4 \mathrm{~ms}$ and mediantinterquartile range in our study.

Along with the study by Lin et al,(11) our study provides the longest available follow-up data of electrical parameters for LV leads, with an average follow-up of one year. Overall, there was a slight reduction in capture thresholds at follow-up, which was more marked for the two most proximal electrodes of spiral leads. Pacing impedance for E1 fell slightly for all three lead models, while the impedances of the proximal electrodes slightly increased. These observations may be due to the iridium oxide coating of the electrodes, better tissue contact of the electrodes with time, and/or to tributary vein thrombosis and stabilisation of the lead.

Study limitations: Blank data fields for threshold measurements (present in $21.7 \%$ of fields) were assumed to be non-capture (i.e. reported as $>2.5 \mathrm{~V} / 0.4 \mathrm{~ms}$ ), which is very likely to have yielded a conservative analysis of overall lead performance. However, potential omissions in data reporting are likely to have involved the three lead models to a similar extent, without unduly affecting their comparison. Pulse widths may have been increased by investigators during the duration of the study in case of elevated thresholds; threshold tests may have not been performed at $0.4 \mathrm{~ms}$ pulsewidth as stipulated in the protocol, which may have accounted for the observed decrease in threshold amplitude over follow-up. PNS was reported according to clinical observation, and not sought after systematically and may therefore have been underreported. However, adverse events resulting from PNS (e.g. requirement for reprogramming or reintervention) were captured, and we therefore believe that most clinically-relevant cases have been reported in our study. 


\section{CONCLUSION}

Various lead designs have been developed to accommodate for different coronary sinus anatomies. Basal and mid-ventricular pacing sites are usually desirable, but capture thresholds increase with more proximal electrodes of quadripolar leads. Nevertheless, straight and spiral leads provide thresholds of $<2.5 \mathrm{~V} / 0,4 \mathrm{~ms}$ in at least one of the proximal electrodes in $>80 \%$ of cases, with lower thresholds in unipolar and extended bipolar configurations, which slightly decrease over follow-up.

\section{Author contributions:}

H.B., T.K. and M.B. participated in the concept and design of the study. H.B. interpretation the data, and drafted the article. T.K. provided the statistical analysis. All authors critically revised and approved the article.

\section{REFERENCES}

1. Turagam MK, Afzal MR, Iskander S, Madhu R, Biase LD, Natale A, Lakkireddy D. 2016. A Meta-Analysis Of Quadripolar Versus Bipolar Left Ventricular Leads On Post-Procedural Outcomes. Journal of atrial fibrillation. 9, 1472.

2. Rijal S, Wolfe J, Rattan R, Durrani A, Althouse AD, Marroquin OC, Jain S, et al. 2017. Lead related complications in quadripolar versus bipolar left ventricular leads. Indian pacing and electrophysiology journal. 17, 3-7.

This article is protected by copyright. All rights reserved. 
3. Leyva F, Zegard A, Qiu T, Acquaye E, Ferrante G, Walton J, Marshall H. 2017. Cardiac Resynchronization Therapy Using Quadripolar Versus Non-Quadripolar Left Ventricular Leads Programmed to Biventricular Pacing With Single-Site Left Ventricular Pacing: Impact on Survival and Heart Failure Hospitalization. Journal of the American Heart Association. 6.

4. Philippon F, Liu L, Fung JW, Deharo JC, Anselme F, Delnoy PP, Crijns H, et al. 2015. Left Ventricular Three-Dimensional Quadripolar Lead Acute Clinical Study: The LILAC Study. Pacing and clinical electrophysiology : PACE. 38, 438-447.

5. Mittal S, Nair D, Padanilam BJ, Ciuffo A, Gupta N, Gallagher P, Goldner B, et al. 2016. Performance of Anatomically Designed Quadripolar Left Ventricular Leads: Results from the NAVIGATE X4 Clinical Trial. J Cardiovasc Electrophysiol. 27, 1199-1205.

6. Crossley GH, Biffi M, Johnson B, Lin A, Gras D, Hussin A, Cuffio A, et al. 2015. Performance of a novel left ventricular lead with short bipolar spacing for cardiac resynchronization therapy: Primary results of the Attain Performa Quadripolar Left Ventricular Lead Study. Heart rhythm. 12, 751-758.

7. Singh JP, Klein HU, Huang DT, Reek S, Kuniss M, Quesada A, Barsheshet A, et al. 2011. Left Ventricular Lead Position and Clinical Outcome in the Multicenter Automatic Defibrillator Implantation Trial-Cardiac Resynchronization Therapy (MADIT-CRT) Trial. Circulation. 123, 1159-1166.

8. Thebault C, Donal E, Meunier C, Gervais R, Gerritse B, Gold MR, Abraham WT, et al. 2012. Sites of left and right ventricular lead implantation and response to cardiac resynchronization therapy observations from the REVERSE trial. Eur Heart J. 33, 2662-2671.

9. Daubert C, Behar N, Martins RP, Mabo P, Leclercq C. 2017. Avoiding non-responders to cardiac resynchronization therapy: a practical guide. Eur Heart J. 38, 1463-1472. 
10. O'Donnell D, Sperzel J, Thibault B, Rinaldi CA, Pappone C, Gutleben K-J, Leclercq C, et al. 2017. Additional electrodes on the Quartet ${ }^{\mathrm{TM}}$ LV lead provide more programmable pacing options than bipolar and tripolar equivalents. EP Europace. 19, 588-595.

11. Lin AC, Biffi M, Exner DV, Johnson WB, Gras D, Hussin A, Singh B, et al. 2018. Long-term electrical performance of Attain Performa quadripolar left ventricular leads with all steroideluting electrodes: Results from a large worldwide clinical trial. Pacing and clinical electrophysiology : PACE.

12. Burri H, Deharo J, Israel C. 2015. The EHRA book on pacemaker, ICD and CRT troubleshooting: case-based learning with multiple choice questions. Oxford University Press.

\section{Figure legends}
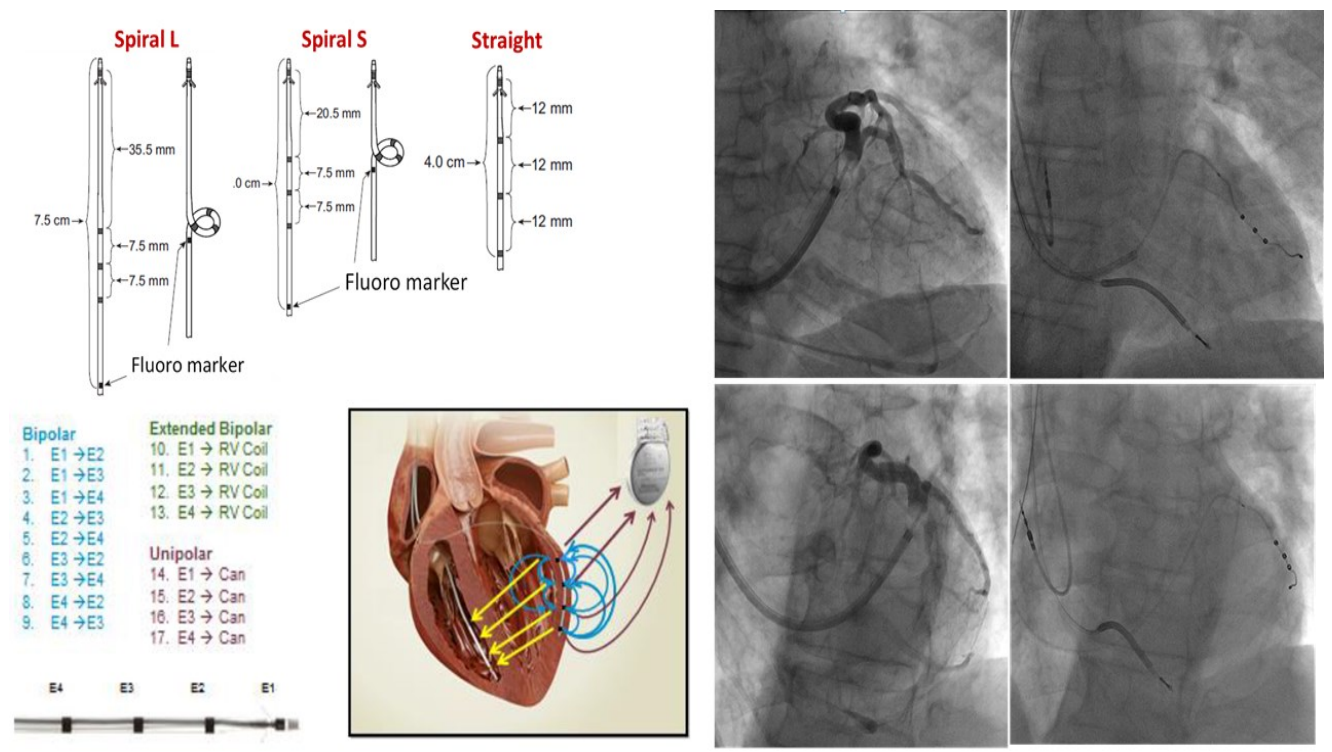

Figure 1: Acuity Spiral long (L), Spiral Short (S) and Straight lead models, with the 17 programmable pacing vectors (including unipolar pacing for CRT-Ds). Spacing between the distal (E1) and most proximal (E4) electrode is comparable between the Acuity Straight and Spiral S leads, and is similar 
to spacing between E1-E2 of the Spiral L lead. All leads have a steroid-eluting collar drug collar near the tip which is separate from the iridium-oxide coated electrodes. On the right, postero-anterior (top) and left anterior oblique (bottom) views of a coronary sinus angiogram are shown, along with final lead position of a Spiral L lead in an apical position of a large lateral tributary (note the proximal fluoroscopic marker which is well within the branch). By virtue of the large spacing of the Sprial L lead, the three proximal electrodes are in a mid-ventricular position.

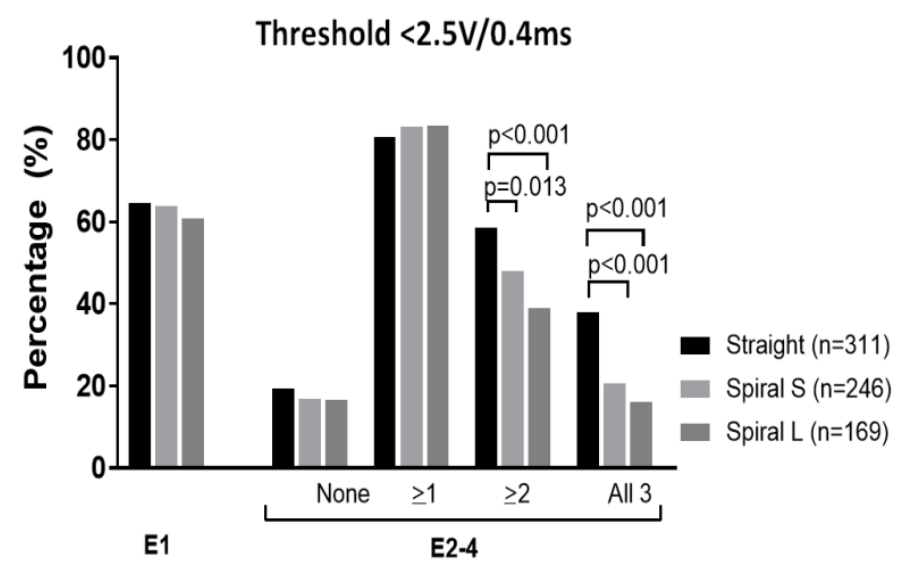

Figure 2: Comparison between lead models for proportion of low capture thresholds ( $<2.5 \mathrm{~V}$ in any polarity) for distal (E1) and proximal (E2-4) electrodes at baseline for Straight, Spiral Short (S) and Spiral Long (L) leads at baseline. Blank data fields (representing $21.7 \%$ of data) were assumed to be non-capture and reported as $>2.5 \mathrm{~V} / 0.4 \mathrm{~ms}$. 

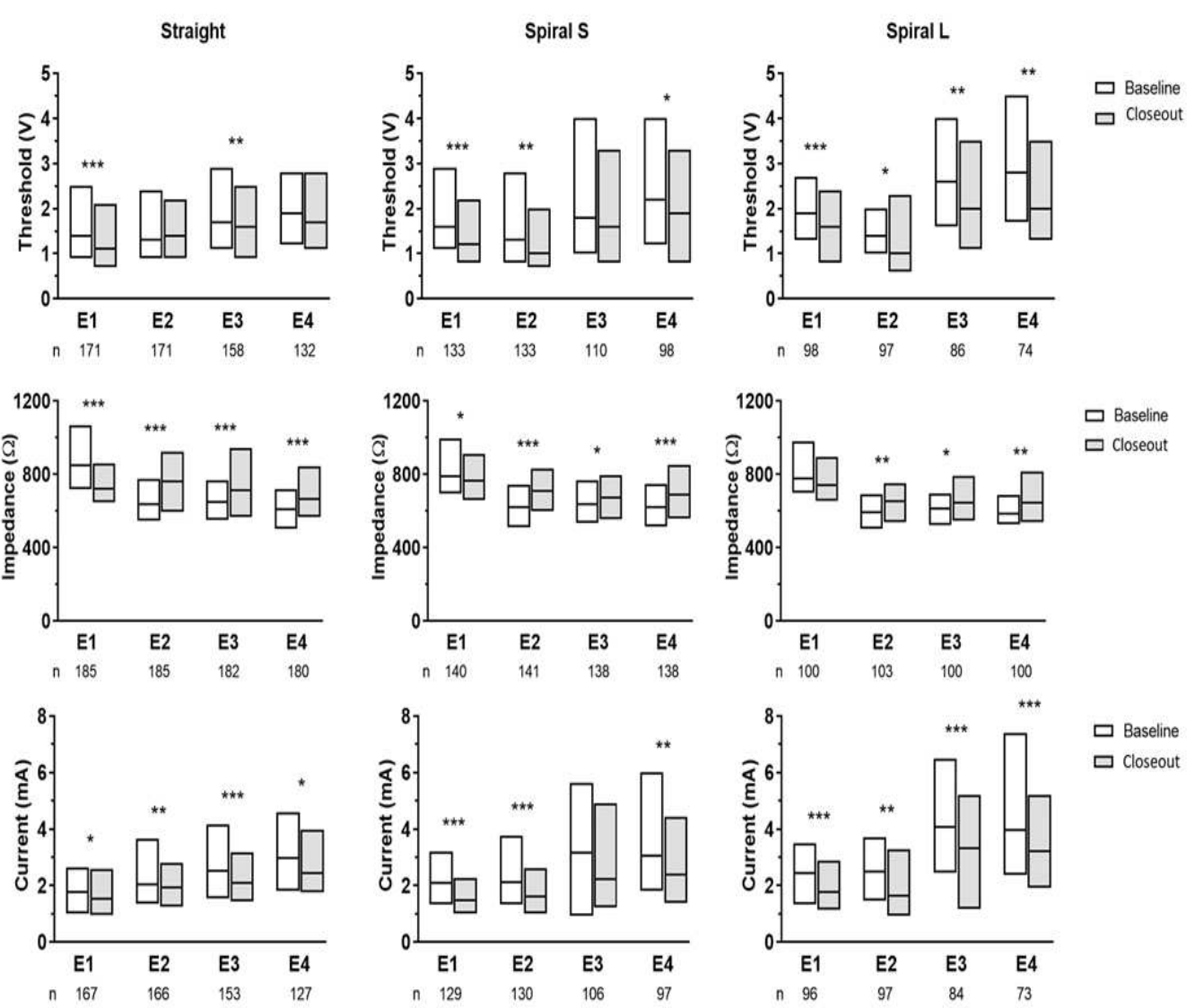

Figure 3. Evolution of unipolar capture thresholds (top) and lead impedances (middle) and approximated current drain calculated by threshold V/R (bottom) at baseline and closeout visits for the different electrodes (actual current drain would depend on programmed output voltage). Data displayed are median and $25^{\text {th }}-75^{\text {th }}$ percentiles. Paired values are shown for each electrode. Not all patients with impedance measurements had capture thresholds reported (e.g. because of lack of capture). $\left.{ }^{* * *} \mathrm{P}<0.001,{ }^{* *} \mathrm{P}<0.01, * \mathrm{P}<0.05\right)$.

Table 1. Baseline characteristics of patients who underwent implantation

\begin{tabular}{|l|c|}
\hline & $\begin{array}{c}\text { Enrolled subjects } \\
\mathbf{n = 8 3 8}\end{array}$ \\
\hline Age (Years) & $67.4 \pm 10.1$ \\
\hline Males & $650(77.6)$ \\
\hline Ischemic cardiopathy & $390(46.5)$ \\
\hline Rhythm disease history & \\
\hline AV block & $217(25.9)$ \\
\hline
\end{tabular}

This article is protected by copyright. All rights reserved. 


\begin{tabular}{|l|c|}
\hline & $\begin{array}{c}\text { Enrolled subjects } \\
\mathbf{n = 8 3 8}\end{array}$ \\
\hline Chronic atrial fibrillation & $158(18.9)$ \\
\hline Paroxysmal atrial fibrillation & $139(16.6)$ \\
\hline Hypertension & $521(63.3)$ \\
\hline Diabetes mellitus & $283(33.8)$ \\
\hline Renal disease & $191(22.8)$ \\
\hline Chronic pulmonary disease & $92(11.0)$ \\
\hline Peripheral artery disease & $48(5.7)$ \\
\hline Cardiac rhythm & \\
\hline Sinus rhythm & $512(61.1)$ \\
\hline Atrial fibrillation & $174(20.8)$ \\
\hline Paced ventricular & $99(11.8)$ \\
\hline Other & $53(6.3)$ \\
\hline QRS morphology & $71(8.5)$ \\
\hline Normal & $76(9.1)$ \\
\hline RBBB & $578(69.0)$ \\
\hline LBBB & $95(11.3)$ \\
\hline NIVCD & $18(2.1)$ \\
\hline Pacemaker dependant or unknown & $158.1 \pm 31.2$ \\
\hline Intrinsic QRS width (ms) & $187.9 \pm 51.8$ \\
\hline Intrinsic PR interval (ms) & $27.1 \pm 5.0$ \\
\hline BMI (kg/m ${ }^{2}$ ) & \\
\hline
\end{tabular}

Percentages are shown in brackets. $A V=$ atrioventricular; $B M I=$ body mass index; $L B B B=l e f t$ bundle branch block; ms=milliseconds; NIVCD=non-specific intraventricular conduction delay; $\mathrm{RBBB}=$ right bundle branch block

Table 2. Lead positions for the different models (according to the distal E1 electrode position).

Numbers of datasets are limited to those provided by corelab analysis.

\begin{tabular}{|l|c|c|c|c|c|}
\hline Lead model & Apical & Mid & Basal & Non Anterior & Anterior \\
\hline $\begin{array}{l}\text { Straight }(\mathrm{N}=195) \\
(4671 \text { or } 4672)\end{array}$ & 43 & 127 & 25 & 189 & 6 \\
$(22.1 \%)$ & $(65.1 \%)$ & $(2.8 \%)$ & $(96.9 \%)$ & $(3.1 \%)$ \\
\hline Spiral Short $(\mathrm{N}=170)$ & $54 * \#$ & 106 & $10^{*} \#(5.9 \%)$ & 165 & 5 \\
$(4674$ or 4675$)$ & $(31.8 \%)$ & $(62.4 \%)$ & & $(97.1 \%$ & $(2.9 \%)$ \\
\hline
\end{tabular}

This article is protected by copyright. All rights reserved. 


\begin{tabular}{|l|c|c|c|c|c|}
\hline Spiral Long $(\mathrm{N}=121)$ & $53^{* *}$ & 67 & $1^{* *}$ & 120 & 1 \\
$(4677$ or 4678$)$ & $(43.8 \%)$ & $(55.3 \%)$ & $(0.8 \%)$ & $(99.2 \%)$ & $(0.8 \%)$ \\
\hline
\end{tabular}

** $\mathrm{P}<0.001$ compared to Straight lead; * $\mathrm{P}<0.05$ compared to Straight lead; \# $\mathrm{P}<0.05$ compared to Spiral long lead.

Table 3. Lead data at baseline (implantation/predischarge). Blank data fields (representing $21.7 \%$ of data) were assumed to be non-capture and reported as $>2.5 \mathrm{~V} / 0.4 \mathrm{~ms}$.

\begin{tabular}{|c|c|c|c|c|c|c|c|c|c|c|c|c|}
\hline Vecto & \multicolumn{4}{|c|}{ Straight $(n=325)$} & \multicolumn{4}{|c|}{ Spiral Short $(n=288)$} & \multicolumn{4}{|c|}{ Spiral Long $(n=182)$} \\
\hline & $\begin{array}{c}\text { Prog } \\
\text { r. } \\
\text { vect }\end{array}$ & $\begin{array}{c}\text { Thresh } \\
\text { old } \\
<2.5 \mathrm{~V}\end{array}$ & $\begin{array}{c}\text { Thresh } \\
\text { old }\end{array}$ & $\begin{array}{c}\text { Impeda } \\
\text { nce }\end{array}$ & $\begin{array}{l}\text { Prog } \\
\text { r. } \\
\text { vect } \\
\text { or }\end{array}$ & $\begin{array}{c}\text { Thresh } \\
\text { old } \\
<2.5 \mathrm{~V}\end{array}$ & $\begin{array}{c}\text { Thresh } \\
\text { old }\end{array}$ & $\begin{array}{c}\text { Impeda } \\
\text { nce }\end{array}$ & $\begin{array}{l}\text { Prog } \\
\text { r. } \\
\text { vect } \\
\text { or }\end{array}$ & $\begin{array}{c}\text { Thresh } \\
\text { old } \\
<2.5 \mathrm{~V}\end{array}$ & $\begin{array}{c}\text { Thresh } \\
\text { old }\end{array}$ & $\begin{array}{c}\text { Impeda } \\
\text { nce }\end{array}$ \\
\hline $\begin{array}{l}\text { E1 } \\
\text { catho }\end{array}$ & $\begin{array}{c}36.7 \\
\%\end{array}$ & & & & $\begin{array}{c}31.7 \\
\%\end{array}$ & & & & $\begin{array}{c}25.9 \\
\%\end{array}$ & & & \\
\hline & $\begin{array}{l}5.9 \\
\%\end{array}$ & $68.1 \%$ & $\begin{array}{l}1.5 \\
{[1.0-} \\
2.8]\end{array}$ & $\begin{array}{c}858 \\
{[740-} \\
1034]\end{array}$ & $\begin{array}{c}6.9 \\
\%\end{array}$ & $54.5 \%$ & $\begin{array}{l}1.9 \mathrm{~V} \\
{[1.2-} \\
2.8]\end{array}$ & $\begin{array}{c}834 \\
{[740-} \\
1034]\end{array}$ & $\begin{array}{c}4.0 \\
\%\end{array}$ & $56.6 \%$ & $\begin{array}{l}2.0 \\
{[1.2-} \\
3.0]\end{array}$ & $\begin{array}{l}815 \\
{[710-} \\
1034]\end{array}$ \\
\hline & $\begin{array}{c}21.5 \\
\%\end{array}$ & $55.4 \%$ & $\begin{array}{l}1.5 \\
{[0.9-} \\
2.7]\end{array}$ & $\begin{array}{l}966^{* *} \\
{[804-} \\
1156]\end{array}$ & $\begin{array}{c}16.3 \\
\%\end{array}$ & $57.3 \%$ & $\begin{array}{l}1.8 \mathrm{~V} \\
{[1.0-} \\
2.7]\end{array}$ & $\begin{array}{l}902^{*} \\
{[705-} \\
1000]\end{array}$ & $\begin{array}{c}12.1 \\
\%\end{array}$ & $56.0 \%$ & $\begin{array}{l}2.0 \\
{[1.2-} \\
2.8]\end{array}$ & $\begin{array}{l}973^{* *} \\
{[823-} \\
1178]\end{array}$ \\
\hline & $\begin{array}{c}8.3 \\
\%\end{array}$ & $52.9 \%$ & $\begin{array}{l}2.1^{* \star} \\
{[1.4-} \\
3.5]\end{array}$ & $\begin{array}{l}1340^{\star \star} \\
{[1132-} \\
1628]\end{array}$ & $\begin{array}{c}6.1 \\
\%\end{array}$ & $43.8 \%$ & $\begin{array}{l}2.5 \\
{[1.7-} \\
4.0]\end{array}$ & $\begin{array}{l}1339 * * \\
{[1142-} \\
1606]\end{array}$ & $\begin{array}{l}6.9 \\
\%\end{array}$ & $42.9 \%$ & $\begin{array}{l}2.6^{* *} \\
{[1.7-} \\
3.8]\end{array}$ & $\begin{array}{l}1331^{\star \star} \\
{[1118-} \\
1594]\end{array}$ \\
\hline $\begin{array}{l}\text { Bipola } \\
\text { r E1- } \\
>\text { E3 }\end{array}$ & 0 & $42.8 \%$ & $\begin{array}{l}2.4^{* \star} \\
{[1.5-} \\
4.0]\end{array}$ & $\begin{array}{c}1468^{\star \star} \\
{[1195-} \\
1755]\end{array}$ & $\begin{array}{l}1.6 \\
\%\end{array}$ & $34.7 \%$ & $\begin{array}{c}2.8 \\
{[1.8-} \\
4.0]\end{array}$ & $\begin{array}{l}1430^{\star *} \\
{[1232-} \\
1640]\end{array}$ & $\begin{array}{c}0.6 \\
\%\end{array}$ & $34.6 \%$ & $\begin{array}{l}2.8^{* *} \\
{[1.9-} \\
3.5]\end{array}$ & $\begin{array}{r}1517^{* *} \\
{[1195-} \\
1718]\end{array}$ \\
\hline $\begin{array}{l}\text { Bipola } \\
\text { r E1- }\end{array}$ & $\begin{array}{l}1.0 \\
\%\end{array}$ & $44.8 \%$ & $\begin{array}{l}2.3^{* *} \\
{[1.5-}\end{array}$ & $\begin{array}{l}1441^{* *} \\
{[1176-}\end{array}$ & $\begin{array}{c}0.8 \\
\%\end{array}$ & $34.4 \%$ & $\begin{array}{r}2.8 \\
{[1.8-}\end{array}$ & $\begin{array}{l}1414^{\star *} \\
{[1237-}\end{array}$ & $\begin{array}{c}2.3 \\
\%\end{array}$ & $34.1 \%$ & $\begin{array}{l}2.8^{\star \star} \\
{[1.8-}\end{array}$ & $\begin{array}{l}1472^{* *} \\
{[1216-}\end{array}$ \\
\hline
\end{tabular}




\begin{tabular}{|c|c|c|c|c|c|c|c|c|c|c|c|c|}
\hline$>\mathrm{E} 4$ & & & $3.5]$ & 1695] & & & $4.0]$ & 1675] & & & $4.0]$ & 1671] \\
\hline $\begin{array}{l}\text { E2 } \\
\text { catho } \\
\text { de }\end{array}$ & $\begin{array}{l}32.7 \\
\%\end{array}$ & & & & $\begin{array}{l}40.7 \\
\%\end{array}$ & & & & $\begin{array}{l}46.9 \\
\%\end{array}$ & & & \\
\hline $\begin{array}{l}\text { Unipol } \\
\text { ar E2- } \\
>\text { Can }\end{array}$ & $\begin{array}{c}5.9 \\
\%\end{array}$ & $69.2 \%$ & $\begin{array}{l}1.5 \\
{[0.9-} \\
2.4]\end{array}$ & $\begin{array}{r}628 \\
{[534-} \\
767]\end{array}$ & $\begin{array}{c}6.9 \\
\%\end{array}$ & $59.0 \%$ & $\begin{array}{c}1.3 \\
{[0.8-} \\
2.6]\end{array}$ & $\begin{array}{c}627 \\
{[524-} \\
750]\end{array}$ & $\begin{array}{c}5.8 \\
\%\end{array}$ & $63.2 \%$ & $\begin{array}{r}1.4 \\
{[1.0-} \\
2.5]\end{array}$ & $\begin{array}{r}594 \\
{[518-} \\
706]\end{array}$ \\
\hline $\begin{array}{l}\text { Ext } \\
\text { Bipola } \\
\text { r E2- } \\
>\text { RV } \\
\text { Coil }\end{array}$ & $\begin{array}{c}20.5 \\
\%\end{array}$ & $61.5 \%$ & $\begin{array}{l}1.2^{\#} \\
{[0.8-} \\
2.3]\end{array}$ & $\begin{array}{l}701^{* *} \\
{[599-} \\
826]\end{array}$ & $\begin{array}{c}21.6 \\
\%\end{array}$ & $62.2 \%$ & $\begin{array}{l}1.3 \\
{[0.7-} \\
2.4]\end{array}$ & $\begin{array}{l}649 \# \\
{[569-} \\
784]\end{array}$ & $\begin{array}{c}29.5 \\
\%\end{array}$ & $62.1 \%$ & $\begin{array}{r}1.3 \\
{[0.9-} \\
2.4]\end{array}$ & $\begin{array}{l}652^{\star \star} \\
{[590-} \\
752]\end{array}$ \\
\hline $\begin{array}{l}\text { Bipola } \\
\text { r E2- } \\
>\text { E3 }\end{array}$ & $\begin{array}{c}4.3 \\
\%\end{array}$ & $49.5 \%$ & $\begin{array}{l}2.3^{\star \star} \\
{[1.5-} \\
3.4]\end{array}$ & $\begin{array}{l}1138^{* *} \\
{[966-} \\
1336]\end{array}$ & $\begin{array}{c}9.8 \\
\%\end{array}$ & $52.8 \%$ & $\begin{array}{l}2.0^{\star \star} \\
{[1.3-} \\
3.3]\end{array}$ & $\begin{array}{l}1052 \\
{[909-} \\
1306]\end{array}$ & $\begin{array}{c}8.7 \\
\%\end{array}$ & $50.6 \%$ & $\begin{array}{l}2.1^{* *} \\
{[1.6-} \\
3.4]\end{array}$ & $\begin{array}{l}1013^{\star \star} \\
{[836-} \\
1147]\end{array}$ \\
\hline $\begin{array}{l}\text { Bipola } \\
\text { r E2- } \\
>\text { E4 }\end{array}$ & $\begin{array}{c}2.0 \\
\%\end{array}$ & $48.3 \%$ & $\begin{array}{r}2.3 \\
{[1.5-} \\
3.3]\end{array}$ & $\begin{array}{c}1128^{* *} \\
{[963-} \\
1319]\end{array}$ & $\begin{array}{c}2.4 \\
\%\end{array}$ & $52.1 \%$ & $\begin{array}{l}2.0^{\star *} \\
{[1.3-} \\
3.3]\end{array}$ & $\begin{array}{l}1094 \\
{[926-} \\
1327]\end{array}$ & $\begin{array}{c}2.9 \\
\%\end{array}$ & $50.6 \%$ & $\begin{array}{l}2.2^{\star *} \\
{[1.5-} \\
3.5]\end{array}$ & $\begin{array}{l}1034^{* \star} \\
{[874-} \\
1176]\end{array}$ \\
\hline $\begin{array}{l}\text { E3 } \\
\text { catho } \\
\text { de }\end{array}$ & $\begin{array}{l}17.5 \\
\%\end{array}$ & & & & $\begin{array}{c}13.8 \\
\%\end{array}$ & & & & $\begin{array}{c}22.5 \\
\%\end{array}$ & & & \\
\hline $\begin{array}{l}\text { Unipol } \\
\text { ar E3- } \\
>\text { Can }\end{array}$ & $\begin{array}{c}4.6 \\
\%\end{array}$ & $54.2 \%$ & $\begin{array}{r}1.8 \\
{[1.1-} \\
3.0]\end{array}$ & $\begin{array}{l}647 \\
{[549-} \\
765]\end{array}$ & $\begin{array}{c}2.0 \\
\%\end{array}$ & $41.0 \%$ & $\begin{array}{l}2.1 \\
{[1.1-} \\
4.0]\end{array}$ & $\begin{array}{c}643 \\
{[543-} \\
768]\end{array}$ & $\begin{array}{l}1.7 \\
\%\end{array}$ & $37.9 \%$ & $\begin{array}{r}2.6 \\
{[1.5-} \\
4.5]\end{array}$ & $\begin{array}{r}617 \\
{[524-} \\
718]\end{array}$ \\
\hline $\begin{array}{l}\text { Ext. } \\
\text { Bipola } \\
\text { r E3- } \\
>\text { RV } \\
\text { Coil }\end{array}$ & $\begin{array}{c}8.9 \\
\%\end{array}$ & $51.1 \%$ & $\begin{array}{l}1.8 \\
{[1.0-} \\
2.7]\end{array}$ & $\begin{array}{l}691^{* *} \\
{[595-} \\
828]\end{array}$ & $\begin{array}{c}6.9 \\
\%\end{array}$ & $42.7 \%$ & $\begin{array}{l}2.1 \\
1.1- \\
3.6]\end{array}$ & $\begin{array}{c}673^{\#} \\
\\
{[581-} \\
793]\end{array}$ & $\begin{array}{c}9.2 \\
\%\end{array}$ & $40.7 \%$ & $\begin{array}{r}2.3 \\
{[1.2-} \\
3.5]\end{array}$ & $\begin{array}{l}673^{\star *} \\
{[594-} \\
776]\end{array}$ \\
\hline $\begin{array}{l}\text { Bipola } \\
\text { r E3- } \\
>\text { E2 }\end{array}$ & $\begin{array}{l}1.7 \\
\%\end{array}$ & $33.2 \%$ & $\begin{array}{l}2.7^{* *} \\
{[1.8-} \\
4.0]\end{array}$ & $\begin{array}{c}1176^{* *} \\
{[978-} \\
1356]\end{array}$ & $\begin{array}{c}2.0 \\
\%\end{array}$ & $31.2 \%$ & $\begin{array}{l}2.8^{* *} \\
{[1.7-} \\
4.5]\end{array}$ & $\begin{array}{c}1098^{* *} \\
{[941-} \\
1346]\end{array}$ & $\begin{array}{c}3.5 \\
\%\end{array}$ & $29.7 \%$ & $\begin{array}{l}2.9^{*} \\
{[2.0-} \\
4.5]\end{array}$ & $\begin{array}{l}1082^{\star *} \\
{[926-} \\
1271]\end{array}$ \\
\hline $\begin{array}{l}\text { Bipola } \\
\text { r E3- } \\
>\text { E4 }\end{array}$ & $\begin{array}{c}2.3 \\
\%\end{array}$ & $38.5 \%$ & $\begin{array}{l}2.5^{\star \star} \\
{[1.7-}\end{array}$ & $\begin{array}{l}1096^{\star \star} \\
{[902-}\end{array}$ & $\begin{array}{c}2.9 \\
\%\end{array}$ & $31.6 \%$ & $\begin{array}{l}2.8^{* *} \\
{[1.8-}\end{array}$ & $\begin{array}{l}1058^{* *} \\
{[902-}\end{array}$ & $\begin{array}{l}1.2 \\
\%\end{array}$ & $27.5 \%$ & $\begin{array}{l}3.0^{*} \\
{[2.1-}\end{array}$ & $\begin{array}{r}1005^{\star \star} \\
{[830-}\end{array}$ \\
\hline
\end{tabular}




\begin{tabular}{|c|c|c|c|c|c|c|c|c|c|c|c|c|}
\hline & & & $4.0]$ & 1289] & & & 4 4.5] & 1271] & & & 5.0] & 1005] \\
\hline $\begin{array}{l}\text { E4 } \\
\text { catho } \\
\text { de }\end{array}$ & $\begin{array}{c}13.2 \\
\%\end{array}$ & & & & $\begin{array}{c}13.5 \\
\%\end{array}$ & & & & $\begin{array}{c}11.6 \\
\%\end{array}$ & & & \\
\hline $\begin{array}{l}\text { Unipol } \\
\text { ar E4- } \\
>\text { Can }\end{array}$ & $\begin{array}{c}5.3 \\
\%\end{array}$ & $46.2 \%$ & $\begin{array}{r}2.1 \\
{[1.3-} \\
3.2]\end{array}$ & $\begin{array}{l}603 \\
{[502-} \\
721]\end{array}$ & $\begin{array}{c}2.9 \\
\%\end{array}$ & $30.0 \%$ & $\begin{array}{r}2.6 \\
{[1.4-} \\
4.5]\end{array}$ & $\begin{array}{l}634 \\
{[523-} \\
747]\end{array}$ & $\begin{array}{c}2.3 \\
\%\end{array}$ & $27,5 \%$ & $\begin{array}{r}3.3 \\
{[1.9-} \\
5.0]\end{array}$ & $\begin{array}{c}587 \\
{[521-} \\
692]\end{array}$ \\
\hline $\begin{array}{l}\text { Ext } \\
\text { Bipola } \\
\text { r E4- } \\
>\text { RV } \\
\text { Coil }\end{array}$ & $\begin{array}{c}5.9 \\
\%\end{array}$ & $41.2 \%$ & $\begin{array}{r}2.0 \\
{[1.2-} \\
3.3]\end{array}$ & $\begin{array}{l}650^{* *} \\
{[571-} \\
792]\end{array}$ & $\begin{array}{c}6.9 \\
\%\end{array}$ & $30.6 \%$ & $\begin{array}{r}2.6 \\
{[1.5-} \\
4.0]\end{array}$ & $\begin{array}{c}654^{\star *} \\
{[556-} \\
784]\end{array}$ & $\begin{array}{c}7.5 \\
\%\end{array}$ & $29.7 \%$ & $\begin{array}{l}2.7 \\
{[1.6-} \\
4.5]\end{array}$ & $\begin{array}{l}635^{*} \\
{[565-} \\
732]\end{array}$ \\
\hline $\begin{array}{l}\text { Bipola } \\
\text { r E4- } \\
>\text { E2 }\end{array}$ & $\begin{array}{c}0.7 \\
\%\end{array}$ & $22.5 \%$ & $\begin{array}{l}3.1^{* \star} \\
{[1.9-} \\
4.5]\end{array}$ & $\begin{array}{c}1290^{* *} \\
{[1069-} \\
1491]\end{array}$ & $\begin{array}{c}0.8 \\
\%\end{array}$ & $21.2 \%$ & $\begin{array}{l}3.2 \\
{[1.9-} \\
4.5]\end{array}$ & $\begin{array}{r}1180^{* *} \\
{[1026-} \\
1406]\end{array}$ & $\begin{array}{c}0.6 \\
\%\end{array}$ & $19.2 \%$ & $\begin{array}{l}3.3 \\
\\
{[2.1-} \\
4.5]\end{array}$ & $\begin{array}{l}1186^{\star \star} \\
{[1054-} \\
1327]\end{array}$ \\
\hline $\begin{array}{l}\text { Bipola } \\
\text { r E4- } \\
>\text { E3 }\end{array}$ & $\begin{array}{c}1.3 \\
\%\end{array}$ & $23.1 \%$ & $\begin{array}{l}3.0^{\star \star} \\
{[2.0-} \\
4.0]\end{array}$ & $\begin{array}{c}1210^{* *} \\
{[1026-} \\
1471]\end{array}$ & $\begin{array}{c}2.9 \\
\%\end{array}$ & $20.5 \%$ & $\begin{array}{l}3.2^{* *} \\
{[1.8-} \\
5.0]\end{array}$ & $\begin{array}{l}1144^{\star \star} \\
{[991-} \\
1373]\end{array}$ & $\begin{array}{c}1.2 \\
\%\end{array}$ & $20.3 \%$ & $\begin{array}{l}3.3 \\
\\
{[2.2-} \\
5.0]\end{array}$ & $\begin{array}{l}1132^{\star \star} \\
{[989-} \\
1297]\end{array}$ \\
\hline
\end{tabular}

Values are shown as median and $25^{\text {th }}-75^{\text {th }}$ percentiles. \# $\mathrm{P}<0.05$ * $^{*} \mathrm{P}<0.01 ; * * \mathrm{P}<0.001$ compared to the unipolar configuration for the electrode acting as cathode. Thresholds reported at $0.4 \mathrm{~ms}$ pulsewidth. 